\title{
The benefits and challenges of machinery sharing among small-scale fruit and vegetable growers
}

\author{
Georgeanne Artz ${ }^{a *}$ and Linda Naeve ${ }^{\mathrm{b}}$ \\ Iowa State University
}

Submitted September 1, 2015 / Revised November 6 and December 11, 2015, and January 19

and January 23, 2016 / Accepted January 25, 2016 / Published online May 19, 2016

Citation: Artz, G., \& Naeve, L. (2016). The benefits and challenges of machinery sharing among

small-scale fruit and vegetable growers. Journal of Agriculture, Food Systems, and Community

Development, 6(3), 19-35. http://dx.doi.org/10.5304/jafscd.2016.063.003

Copyright (C) 2016 by New Leaf Associates, Inc.

\begin{abstract}
We worked with five groups of Iowa farmers who shared different pieces of machinery. Under our mentoring, each group developed sharing agreements; some groups continue to share equipment and other inputs. In this paper, we provide an overview of the project and case studies of machinery sharing as well as summarize the benefits and challenges faced by growers during the first year in machinery-sharing arrangements. Our results suggest that in addition to allowing growers to cost-effectively access specialized equipment and improve their labor efficiency,

a* Corresponding author: Georgeanne Artz, Assistant Professor, Department of Economics; 478B Heady Hall; Iowa State University; Ames, Iowa 50011 USA; +1-515-294-6260; gartz@,iastate.edu

b Linda Naeve, Program Specialist, Extension Value Added Agriculture; 1111 NSRIC; Iowa State University; Ames, Iowa 50011 USA; +1-515-294-8946; $\underline{\text { lnaeve@iastate.edu }}$

\section{Disclosure}

Financial support was provided by Leopold Center for Sustainable Agriculture and the USDA Rural BusinessCooperative Service.
\end{abstract}

sharing can provide other benefits, including improved access to skilled labor, reduced risk, and idea sharing among peer groups of like-minded individuals. Commonly cited concerns with machinery-sharing arrangements, including having access to the equipment when most needed, can be alleviated with careful advanced planning and open communication.

\section{Keywords}

equipment, fruit, local foods, machinery sharing, small-scale producers, vegetable

\section{Introduction and Literature Review}

Interest in local foods has been growing among both consumers and producers. According to U.S. Secretary of Agriculture Tom Vilsack, "The demand for local food is growing rapidly nationwide, creating more opportunities for American farmers and ranchers and growing the entire country's rural economy" (U.S. Department of Agriculture [USDA], 2014). While the growth of direct-to-consumer sales, such as farmers markets and CSAs, is peaking, sales to intermediate markets 
are skyrocketing. As a result, the current economic opportunities in local food extend beyond small markets, and an increasing number of local growers are entering the marketing mainstream through wholesale markets (Low et al., 2015).

Supplying wholesale markets presents a challenge for the local foods industry. While direct-toconsumer sales is a good entry point for beginning producers, wholesale markets typically require growers to supply much larger volumes and greater delivery consistency in product at lower prices than retail markets. The challenge facing the local food movement is farmers' capacity and willingness to scale up to meet the demand of these intermediate market channels (Mount, 2012). Most farms engaged in local foods production are small and many are not profitable, if unpaid family labor is included (Brown \& Miller, 2008). These farms make up 85 percent of farms selling local foods, but account for only 13 percent of the total local food sales, primarily through direct-to-consumer channels (Low et al., 2015). Approximately 60 percent of the value of local food sales is marketed through intermediate channels, such as grocery stores and restaurants, by larger volume food farms (Low \& Vogel, 2011).

Increasing production for intermediate markets can increase farms' efficiency and profitability (Low et al., 2015). To scale up their production level, meet the growing interest, and increase profitability, local fruit and vegetable growers need to find ways to increase labor input or improve labor efficiency through mechanization and other means. The financial constraints faced by most small-scale growers, particularly those who are new to agriculture, create an obstacle to scaling up production. Small-scale local food production is typically less mechanized, and therefore more labor intensive, than large-scale production. However, expansion using labor-intensive practices is limited in many cases, because additional labor is unavailable or too costly. Alternatively, farms can adopt more capital-intensive, labor-saving production methods. This strategy has challenges as well. Labor-saving machinery, particularly specialized equipment, is a "lumpy input" that must be adopted in discrete amounts. Purchasing machinery, even used machinery, usually requires a signif- icant financial investment and adequate cash flow, making the investment economically infeasible for small-scale growers. While expanding production to take advantage of size economies helps to manage the associated rise in fixed costs of equipment (Johnson \& Ruttan, 1994), purchasing the machinery complement required to expand from a 5-acre (2-hectare) market farm to a 20 -acre (8. ha) vegetable farm requires more cash than many smallscale producers can afford. ${ }^{1}$

Given these constraints, some growers are considering alternative ways to access machinery, including the option of sharing equipment with other growers. Evidence from a survey of fortyfour fruit and vegetable growers, undertaken in January 2012, supports the idea that such growers have an interest in sharing machinery to reduce costs (Artz, Edwards, \& Jarboe, 2014). Seventy percent of the respondents answered they would consider sharing equipment with other growers. Additional post-workshop surveys conducted with producers in the winter of 2014 showed that 39 percent had shared machinery and 85 percent were interested in sharing machinery. The reasons cited for sharing included: enabling access to machinery that would otherwise not be affordable, saving time and cost, and intending to scale up but lacking access to sufficient labor to do so. Among the concerns raised about sharing machinery were not having immediate access to the machine when it is needed, financial and time constraints for transporting the equipment, and the challenge of finding suitable sharing partners.

Small-scale fruit and vegetable growers may face some unique challenges for sharing machinery, because, relative to corn and soybean row crop operators, they use more diverse and specialized equipment, such as transplanters, bed shapers, planters for multiple-sized seed, mulch layers, mulch removers, rotovators, and potato and root crop diggers. Also, because the density of fruit and

\footnotetext{
${ }^{1}$ John Hendrickson (2005) provides a sample of the purchase price of a machinery set for a 5 -acre (2 ha) market farm costing US $\$ 35,400$. His estimates for a 20 -acre (8 ha) vegetable farm ranges from a low US $\$ 42,725$, if all equipment could be purchased used, to as much as US $\$ 165,000$ for purchasing all new machinery.
} 
vegetable growers in this region is low and they tend to be dispersed geographically, sharing machinery among fruit and vegetable growers involves more complex transportation arrangements and logistics of scheduling use. In contrast, corn and soybean row crop operators in the rural Midwest typically have a large pool of nearby potential equipment-sharing partners. Finally, many specialty crop growers are new to agriculture and are not experienced equipment operators, raising an additional question of whether these growers possess the necessary skills required to safely and properly operate machinery that may be shared.

Equipment and labor sharing among farms is not a new concept. For example, U.S. farmers in the early part of the $20^{\text {th }}$ century routinely worked together to harvest crops on threshing rings (Olmstead \& Rhode, 1995). Harper (2001) describes the practice of "changing works" in upstate New York, in which neighboring farmers worked cooperatively to harvest oats, hay, and corn, moving from one farm to the next. This tradition of working together on collective tasks virtually disappeared after World War II, he argues, a result of declining agricultural labor supply and technological changes in production, including increased mechanization. Today, informal and occasional machinery and labor sharing among farms in the U.S. is still relatively common. However, more formalized, routine equipment sharing among non-related partners seems quite rare; at least, U.S.-focused research on the topic is limited. Artz, Colson, and Ginder (2010) describe several cases of regular, on-going equipment sharing among conventional row crop growers in the Midwest. A few simulation studies have examined the potential costs and benefits of machinery sharing, showing conditions under which it may be profit-enhancing (e.g., Kenkel \& Long, 2007a; Wolfley, Mjelde, Klinefelter, \& Salin, 2011) and a handful of University Extension publications provide guidance on ways to organize joint ownership of machinery (e.g., Artz, Edwards, \& Olson, 2009; Edwards, 2013; Kenkel \& Long, 2007b; Weness, 2001).

Machinery rings and other more formal farmlevel cooperative arrangements among non-related producers appear to be more common in Europe and Canada than in the U.S. Harris and Fulton (2000a) report more than 1,000 member farms in forty-seven CUMA's (“Coopérative d'Utilisation de Matériel Agricole-loosely translated as "cooperative for the use of farm implements") in Quebec. A report on the socio-economic impacts of rural business rings in Scotland includes an estimate that 23 percent of Scottish farmers belong to machinery rings (Scottish Agricultural Organisation Society, 2008). de Toro and Hansson (2004) report 5,000 members in 20 associations in Sweden (about six percent of Swedish farmers). They compare this participation rate to that in Germany, noting that Swedish activity would need to increase fivefold to reach the level in Germany. While it remains an open question whether more U.S. growers would adopt machinery sharing strategies in their operations, the successful models in other regions of the world suggests the possibility.

We investigated the potential for machinery sharing among small-scale fruit and vegetable growers in a project conducted in Iowa in 2013. We worked with newly established groups of producers with different types of machinery and different sharing strategies. Our first objective in the machinery-sharing project was to explore alternative strategies for equipment ownership that growers could implement in their operations to enhance profitability and reduce risk when scaling up production. Our second objective was to document the economic and other costs and benefits experienced by the growers participating in the sharing arrangements. Third, we sought key lessons to guide other growers considering sharing equipment.

\section{A Conceptual Framework for Machinery Sharing} Machinery sharing is a form of horizontal cooperation that involves trading-off potential savings and increased costs. The savings arise from reduced investment and internal economics of scale. Added costs include both explicit costs, such as transportation costs of moving equipment between farms, and implicit costs, especially increased transaction costs due to lost timeliness, monitoring, and group decision-making (Allen \& Lueck, 1998; Hansmann, 2000; Valentinov, 2007). The potential benefits and costs of sharing machinery relative to individual 
ownership can vary greatly depending on a variety of factors, such as size of the group, type of equipment shared, size of members' farming operations, and even members' personalities (Artz, Colson, \& Ginder, 2010; Wolfley et al., 2011). A motivating factor for many producers considering sharing machinery is the reduced upfront investment required to acquire the equipment. Dividing the cost of equipment among multiple farms can dramatically lower the amount of capital investment needed at the time of purchase, but the cost savings can extend beyond the initial investment. Some studies of machinery cooperatives have reported cost savings as high as 30\% to $35 \%$ (Harris \& Fulton, 2000b; Kenkel \& Long, 2007a), while others have found more modest, yet still positive gains, depending on the organization of the arrangement and the type of farming system (de Toro \& Hanson, 2004; Wolfley et al., 2011). Savings arise from an ability to improve efficiency in the production process as the size of a farm increases, because the number of acres serviced by the machinery increases (relative to individual use), lowering per-unit costs of production (Basnet \& Kenkel, 2012; Gertler, 1981; Gertler \& Murphy, 1987; Weness, 2001). Sharing may allow producers access to more efficient, larger, or more specialized equipment and technology than they could otherwise afford (Groger, 1981; Harris \& Fulton, 2000a, 2000b; Samuelsson, Larsén, Lagerkvist, \& Andersson, 2008). The access to such farming equipment can improve productivity and quality, and replace expensive or hard to find labor (Artz, Colson, \& Ginder, 2010; Nielsen, 1999). If the sharing arrangements allow for timely access, higher capacity equipment can reduce the time spent to complete critical operations (e.g., planting or harvesting), both lowering costs and production risk (Andersson et al., 2005; de Toro \& Hansson, 2004; Kenkel \& Long, 2007b; Wolfley et al., 2011). Working cooperatively, group members can improve labor productivity by specializing in the tasks they are best at or most enjoy, and by coordinating tasks to reduce duplication (Allen \& Lueck, 1998).

The practice of sharing equipment and perhaps labor may spark other forms of collaboration among cooperating farms, generating further benefits. Working cooperatively with others may facilitate sharing of experiences and ideas. The cooperative relationships may lead to coordinated purchases of inputs to access volume discounts, or to working jointly to obtain better terms for credit, storage, services and marketing, and distribution opportunities (Johnson \& Ruttan, 1994). Cooperators may be able to coordinate production processes to attract specialty contracts that pay premiums for delivery of a product in bulk or of a certain quality (Sexton \& Iskow, 1988). Finally, sharing may create opportunities for custom work, adding an additional income source for small farmers.

At the same time, sharing machinery across farms can introduce a number of costs not incurred when owning equipment individually, and it will not always be the case that the benefits of acting collectively outweigh the costs. As Ostrom (1990) notes, "the costs involved in transforming a situation from one in which individuals act independently to one in which they coordinate activities can be quite high" (p. 40). If member farms are geographically dispersed, the costs of transporting the equipment between farms can be substantial. Legal or accounting services may be required at the time of formation and also possibly on an ongoing basis. Beyond these explicit costs, a number of implicit costs of sharing may arise. Joint owners of an asset do not necessarily share equally in the costs and benefits of that asset. As a result, joint ownership inherently produces conflicts of interest (Holderness, 2003). Artz (2014) discusses five overlapping categories of potential conflicts associated with shared use and ownership of an asset: scheduling of use and timeliness concerns; moral hazard or free-riding problems; costs of collective decision making; opportunism and hold up problems; and risk. Studies of sharing have documented examples of these, including less timeliness in field operations, less control over decision making and reduced independence, more complex management, potential problems with lenders and split lines of credit, and challenges in unwinding arrangements (see Andersson et al., 2005; de Toro \& Hansson, 2004; Gertler, 1981; Gertler \& Murphy, 1987; Groger, 1981; Harris \& Fulton, 2000a, 2000b; Nielsen, 1999; Samuelsson et al., 
2008; Wolfley et al., 2011). Many of these potential costs, however, can be minimal in cases of machinery sharing among small, relatively homogeneous groups of producers with common interests. Frequent interaction among group members can allow for monitoring to prevent moral hazard problems. Personal relationships and repeated interactions, or in some cases, legally enforceable contracts, can help solve problems with free-riding and opportunism (Hansmann, 2000; Larsén, 2007).

\section{Applied Research Methods}

We examined the trade-offs between the added benefits and increased costs of interfarm cooperation through equipment sharing in a set of five cases of newly formed machinery-sharing groups located in Iowa. We focused our study on smallscale fruit and vegetable producers, but the cases represent variety in the type of equipment shared, farming experience, and number of producers involved. These differences in inter-farm cooperation allow us to better understand how group size and nature of equipment shared affect the effectiveness of the groups.

We used a multiple case design in which the unit of analysis is the machinery-sharing group. While case-study approaches are well-suited for gaining a deeper understanding of emerging or relatively rare events and for asking "why" and "how" questions, there are limitations (Kennedy \& Luzar, 1999; Sterns, Schweikhardt, \& Peterson, 1998; Westgren \& Zering, 1998; Yin, 2003). In particular, while our findings should not be interpreted as representing the characteristics of the population of farmers (Yin, 2003), the case approach we use in this study enables us to illustrate a range of organizational forms and strategies used in sharing machinery among Iowa fruit and vegetable producers, to document differences across these cases, and to analyze the situational characteristics that were associated with successful and unsuccessful outcomes.

We identified potential case study participants using a snowball sampling approach. In February 2013, we contacted farmer organizations, Extension media resources, and individuals involved in the local foods movement, value-added agriculture, and fruit and vegetable production. We asked them to publicize our project among commercial fruit and vegetable growers in Iowa and to solicit applications from growers. Interested growers completed an application form that included the contact information of the lead partner and one or more committed partners, the total number of acres in fruit and vegetable production among all participants, and the piece of equipment they planned to purchase and share. We used this information to select a diverse set of five groups of various production scales and products. ${ }^{2}$ Eighteen farmers received compensation for participating in the project, paid in two installments: one at the beginning of the project and the remainder after the final survey was completed. Participants were encouraged to use the monetary compensation toward the purchase price and/or maintenance of the shared equipment. Prior to the growing season, an orientation teleconference was held with the farmers to discuss expectations of participating in the project, procedures, the timeline for accomplishing project goals, and how the compensation for their participation would be dispersed. All participants completed a preliminary questionnaire (see Appendix) to collect information about the respective group members' motivations for sharing and basic information about their farming operations. All groups had purchased or acquired their respective machinery by late spring. Tables 1 and 2 provide brief descriptions of the case study participants. ${ }^{3}$ The groups varied in size from two to eight members. Each group shared a different type of equipment. While four of the groups had relatively simple operating agreements, one group organized as a limited liability company. This was the largest group in the study, with eight participating farms,

\footnotetext{
2 We submitted our research proposal to our university's Institutional Review Board and were granted 'exempt' status for the study.

${ }^{3}$ Six groups were originally selected to participate. However, one group dissolved before they purchased the equipment, primarily because the key organizer for the group decided to pursue a full-time opportunity off-farm and quit farming. In addition, another member in the group worked full-time offfarm, which made it difficult to meet with the other farmers. He was a beginning commercial vegetable producer who farmed approximately 30 miles $(48.2 \mathrm{~km})$ from the other two members in the group.
} 
and also the group which purchased the most expensive equipment, a US $\$ 30,000$ aronia berry harvester. $^{4}$

Each group was required to develop a machinery-sharing agreement and follow it throughout the 2013 growing season. We provided operating agreement templates with suggested provisions to the groups and we assisted them in developing their sharing agreements, which provided detailed answers to the following questions:

\section{Ownership}

- Who owns the machinery? (Percentages per owner)

- In the event an owner withdraws, how will his/her shared ownership be liquidated? How much advance notice is required to withdraw from the agreement?
- May the machinery be loaned or custom hired to parties not included in the agreement?

- Who will be responsible for insuring the jointlyowned machinery?

Storage

- Where will the machinery be stored (short term and long term)? Will compensation be paid for storing machinery?

Operation, Maintenance, Record-keeping

- How will fuel be supplied for tractors and selfpropelled equipment?

- Who will be responsible for performing repairs and maintenance? How will operating and repair costs be calculated, collected, and paid? Who will have responsibility for paying joint expenses and other obligations?

\section{Table 1. Brief Descriptions of the Cases}

\section{Holland Mulch Layer Model 1275}

Two producers, located about 30 miles $(48.3 \mathrm{~km}$ ) apart, jointly purchased a Holland Transplanter Mulch Layer. Neither farmer had additional hired labor and both were looking to expand production. Given the infrequent use of the plastic laying equipment, and the ability to adjust the machine to different tractors, sharing was a good option. They financed the purchase $50 / 50$ and share equally in operating costs.

\section{Univerco ECO I Weeder}

This group of three older small-scale vegetable growers was looking for a cost-effective alternative to labor-intensive weed control. They jointly purchased a single-row ECO 1 mechanical weeder, each contributing one-third of the purchase cost. They have managed the challenge of sharing a piece of frequently used equipment by keeping the group small and staying in close communication during the growing season.

\section{Three-point hitch tool bar and attachments \\ Three younger women growers who were already collaborating through a multi-farm CSA were looking to share equipment that could be easily transported and would serve a variety of needs in their operations. They selected a three-point hitch tool bar with an undercutter and other attachments including high-wing furrowers, cultivator tines and disc hillers. Two of the group members purchased the equipment 50/50, giving the third member the option to rent the equipment for US $\$ 40$ per use.}

\section{Garlic clove separator}

A grower with a seed garlic business built a motorized garlic clove separator as a way to efficiently break and clean over 4,000 pounds $(1,800 \mathrm{~kg})$ of garlic each season. Although the machine cannot easily be moved, he shares it with two other nearby growers who bring their garlic to his farm to be separated. The two cooperating growers each provided 10 percent of the original cost, and they share in annual maintenance costs.

\section{JOANNA-3 aronia harvester}

Eight aronia berry growers formed an LLC to collectively purchase the aronia berry harvester to machine-harvest their increasing number of bearing acres of aronia. Under the direction of a group leader, they share the harvester and labor. Members are charged usage and maintenance fees based on their acreage in aronia production. These fees are contributed to a joint fund from which machinery-related expenses are paid. The usage fees also adjust for the relative usage of the machine by the various members.

${ }^{4}$ For more detailed case study descriptions, see Artz, Naeve, and Edwards (2014). 
- How will each owner or lessee contribute to the operating costs of the machinery?

- How will records be kept and who will be responsible for keeping them?

Labor

- How will labor for operating the machinery be contributed?

Replacement

- What is the goal or strategy for replacing the machinery?

Each group completed an equipment-use time log and financial recordkeeping forms that we developed for their shared equipment. Participants also provided input and suggestions regarding the operation of their specific equipment-sharing model. We evaluated the success of the arrangements in two ways. We held on-site followup meetings with three groups to observe their equipment in operation and to discuss their particular equipment-sharing models. For the other two groups, we conducted follow-up interviews by phone using open-ended questions to generate discussion. The following questions guided our post-season, follow-up interviews with each of the groups:

- Did your group work together to develop the sharing agreement? Was it useful?

- On how many acres was the shared machinery used?

- What markets were used to sell farm products?

- Did your group use the time log to determine the amount of time the machinery was used and the time required for transport and setup? Was this information helpful and how was it used?

- How was the machinery moved between farms and who was responsible for transportation?

- Were adjustments needed prior to each use?

- Was labor shared?

- Was the machinery efficient and effective? How much time do you estimate that it saved?

- Any additional thoughts of sharing other equipment in the future?

\section{Table 2. Equipment Sharing Groups}

\begin{tabular}{|c|c|c|c|c|c|c|}
\hline $\begin{array}{l}\text { Case: } \\
\text { Equipment Shared }\end{array}$ & $\begin{array}{l}\text { No. of } \\
\text { Members }\end{array}$ & $\begin{array}{l}\text { Total No. } \\
\text { of Acres } \\
\text { (Hectares) }\end{array}$ & $\begin{array}{l}\text { Approximate Distance Between } \\
\text { Farms }\end{array}$ & $\begin{array}{l}\text { Age Range of } \\
\text { Growers }\end{array}$ & Type of Ownership & Members with Off-farm Employment \\
\hline $\begin{array}{l}\text { Holland Transplanter } \\
\text { Mulch Layer }\end{array}$ & 2 & $2.25(0.91)$ & 30 miles (48 km) & $27-51$ & Equal co-ownership & 2 work full-time off farm \\
\hline $\begin{array}{l}\text { Multi-use tool bar and } \\
\text { attachments }\end{array}$ & 3 & $4.5(1.8)$ & $18-20$ miles $(29-32 \mathrm{~km})$ & $30-56$ & $\begin{array}{l}\text { Equal co-ownership by two } \\
\text { members }\end{array}$ & 2 work part-time off farm \\
\hline $\begin{array}{l}\text { Joanna } 3 \text { Aronia } \\
\text { Harvester }\end{array}$ & 8 & $40(16)$ & $\begin{array}{l}50-\text { mile radius from a centrally } \\
\text { located farm }(80.5 \mathrm{~km})\end{array}$ & $40-65$ & Equal co-ownership & $\begin{array}{l}3 \text { have full-time off farm } \\
\text { employment }\end{array}$ \\
\hline ECO 1 Weeder & 3 & $10(4)$ & $20-25$ miles $(32-40 \mathrm{~km})$ & $59-70$ & Equal co-ownership & $\begin{array}{l}1 \text { grower works part-time in winter } \\
\& 1 \text { works full-time year round }\end{array}$ \\
\hline Garlic separator & 3 & $5(2.02)$ & $10-30$ miles $(16-48 \mathrm{~km})$ & $26-38$ & Co-ownership: 80:10:10 & 1 works part-time off farm \\
\hline
\end{tabular}


Both interviewers took detailed notes during the interviews and wrote summaries of the conversations shortly after the interviews occurred. We also conducted a brief survey of the 21 participating farmers one year later, in January 2015, to gather information on the effectiveness, growth, and sustainability of their machinery-sharing group and agreement.

\section{Results}

\section{Benefits Realized from Sharing Equipment}

Our case studies show a number of benefits from sharing machinery consistent with previous literature on the topic. These include reduced machinery costs, access to more specialized equipment than would otherwise be attainable, improved efficiency particularly through labor savings, reduced production risks, and additional collaboration.

\section{Reduced costs}

In four of the five cases, sharing machinery did not actually reduce outright expenses since it involved purchasing equipment not previously owned, albeit at a lower expense than would have been the case if each grower had purchased the equipment individually. Since few of these small-scale growers hired labor, the increased equipment expenses were not offset by reduced labor expenses. In these cases, the main benefit of the equipment was realized through reductions in their own labor and improved timeliness of operations.

In the case of the aronia berry harvester, however, the machine did replace hired labor for hand harvesting for the established producers in the group. Based on the group's records, two people operating the harvester could harvest an acre $(0.4$ ha) of berries in 1.75 hours. Thus, growers with small acreage could harvest their crops in a day, including about 90 minutes for setup and cleanup and 90 minutes for transportation. In contrast, hand harvesting an acre of aronia requires an estimated 771 hours of labor. ${ }^{5}$ Clearly, the cost of equipment would be quickly recovered in the labor

${ }^{5}$ Assumes 620 plants per acre $(0.4 \mathrm{ha}), 20 \mathrm{lbs}$. $(9.07 \mathrm{~kg})$ of production per plant, and a picking rate of $16.1 \mathrm{lbs}$./hour $(7.3$ $\mathrm{kg} /$ hour). savings in this example.

Given that our study was confined to the first year of equipment sharing for these groups, we did not observe that any of the growers expanded acreage in this year, although several indicated an intention to do so in the future. For example, the group sharing the aronia berry harvester purchased their machine in anticipation of more acres under production in the near future as their members' young plants reached maturity. However, one of the partners in the mulch layer group did report being able to more fully utilize his available land and produce a greater quantity on the same acreage. In this case, the machinery allowed him to complete the plastic laying task in a fraction of the time and effort required by hand labor.

\section{Access to specialized equipment}

Growers in several cases indicated that they would not have found it affordable or economical to purchase the equipment individually. Certainly, in the case of the US $\$ 30,000$ aronia berry harvester, individual ownership would have been cost prohibitive for the beginning and very small-scale producers in the group. Yet even for a relatively less costly piece of equipment, available funds can be limited for small-scale producers. For example, one grower in the study noted, "I just don't have the funds to purchase a mulch layer on my own."

\section{Improved efficiency and/or labor savings}

Sharing equipment improved efficiency for some of, if not all, the members of the groups, primarily through reduced labor input. For example, in the case of the mulch layer, the growers reported that laying 350 feet $(106.7 \mathrm{~m})$ of plastic previously required two people and two hours; with the equipment, one person could accomplish this same task in minutes. Not only did access to equipment save time, it also saved physical effort. "The weeder saves an awful lot of expenditure of energy. If I had to do it by hand, I couldn't physically get that much done in a day," said one 70-year-old producer in the Eco-Weeder group. One of the women in the toolbar sharing group noted, "the main thing was, we're breaking our backs here [digging root crops]. The tool makes it so much easier." 
The one case in which efficiency was not improved for all of the members was the garlic separator group. For the producer who stored the equipment on farm, and for those in very close proximity with ready access to the machine, sharing did save time and effort and made sense. Data from this group suggests that by hand, one person can break and clean about 25 pounds $(11.4 \mathrm{~kg})$ of garlic per hour, but, due to hand fatigue, can't work at this for more than a few hours at a time. The separator, however, cracks and cleans roughly 500 pounds $(226.8 \mathrm{~kg})$ of garlic per hour. Two of the initial five collaborators ultimately decided not to participate because the machine did not save enough time given that they would have needed to travel a significant distance $(20$ miles $(32 \mathrm{~km})$ or more) to use the machine, which was not portable. Relative to the other growers, one of whom had a garlic seed business, these growers ran more diverse vegetable operations and had much smaller quantities of garlic to separate.

\section{Other benefits}

In addition to cost and labor savings, one group noted the benefit of having "backup" should something go wrong. In the toolbar group, when one grower's tractor broke down during the growing season, she was easily able to borrow a tractor from one of her partners. She noted: "We've learned that working together has been such a great asset, you know when one farmer has a hard time or has a crop failure or has personal issues, and has to pull back a little, the other farmers fill in the gaps." Sharing equipment can lead to other types of sharing as well. Of particular importance is sharing labor. In the Eco-Weeder case, the sharing arrangement gave one partner access to additional help that he did not have before. Labor sharing may happen on a more occasional basis as well; "If we ever have a big project or something that needs to be done, we all kind of work together and share our efforts." Some groups extended their collaboration to purchasing bulk quantities of supplies, such as fertilizer, pesticides, harvest containers, boxes, and plastic mulch. As one grower phrased it, there is "power in numbers for purchasing."

Another benefit of collaboration is companionship, "farming can be lonely sometimes, it's really nice to have a group of like-minded people all working toward the same cause." Similarly, a group of people with whom to share ideas is helpful. One of the aronia growers noted, "The group's dynamics are a plus in decision making. The group has compatible, complementary business and farming skills. If you are the sole owner, the whole burden of problem solving falls on one person, but when you have many heads working on solutions, it is a lot easier and gets done quicker."

\section{Overcoming Potential Challenges Encountered in Sharing Equipment}

Previous studies of equipment sharing have documented a number of potential challenges encountered in these groups. Similarly, in our surveys of growers, we find many growers express a reluctance to consider sharing machinery with others. They worry about having access to the machine when it is needed, dealing with increased communication and transportation costs, and finding compatible partners. For the most part, growers in our study were able to deal effectively with these challenges through advance planning and through frequent and transparent communication.

\section{Timeliness, transportation, and communication costs}

In the literature, interviews with study participants, and grower surveys, one of the most frequently voiced concerns about sharing equipment with other growers is fear of not having access to the shared equipment when it is most needed. This is less of an issue when the use of the equipment is not highly time-sensitive and when it is used relatively infrequently. However, in our study, even groups who shared equipment that was both timesensitive and used often, for example, the EcoWeeder, did not report any major issues or concerns with having access to the shared equipment when it was needed. This is likely due to the advanced planning the groups undertook when formulating their written operating agreement, as well as their constant communication throughout the growing season.

Transporting the equipment between farms was generally not a problem for the equipment- 
sharing groups in this study. In some cases, the equipment was used infrequently and only needed to be moved once or twice during the season. In cases where the equipment was used frequently, having a plan and communicating frequently resolved any issues regarding transportation and access to the machines. In the case of the EcoWeeder, the most frequently used piece of equipment in our study, the three farmers kept in close communication and could usually move the weeder on short notice. They agreed in advance that the weeder would stay at the farm of the last user until requested by another member. The farmer requesting it was responsible for picking it up, but sometimes they would meet the other halfway between the farms. Since the farms were only about 20 miles apart, the sharers found that they could leave home, pick up the weeder, return, and have it ready to use in their field in less than two hours. Portability of equipment is also an important factor in the workability of sharing arrangements. In the toolbar case, the attachment was small enough to fit in the back of a pickup or small SUV, which made it easy to move between farms. In contrast, the garlic separator was not portable, and this restricted the ease of use.

Similarly, the additional communication required for working in a group was not viewed as a burden in these cases, but the need for transparent communication cannot be understated. Only the aronia berry group, the largest in our study, held regular, formal meetings during their formation process. Communication among the other groups occurred on an "as needed" basis, for example, calling or texting the other partners to ask questions or to arrange for transportation. In the case of the garlic separator group, two of the original five partners ultimately chose not to participate, citing lack of clear communication from the group's leader as a major concern. In particular, the specifications of the equipment to be shared were not clearly communicated in this case; the withdrawing producers thought the separator would be moved from farm to farm rather than be fixed in place.

The relative ease with which the groups in the study handled the potential challenges of timeliness, transportation, and communication stemmed from advanced planning, the willingness to be flexible when needed, and limits to the group size. Each of the groups seemed to have a sense of the optimal group size for their sharing agreement. For example, the two partners who shared the mulch layer felt that two to three partners would be the maximum for sharing that piece of equipment, explaining that it would be less effective with more members due to a relatively short window of opportunity for using the machine each season. A member of the Eco-Weeder group noted, "having fewer people sharing it gives us more flexibility on when we can get the machine. It wouldn't work as efficiently with more people or larger farms." Similarly, the aronia berry group limited their membership to no more than ten participating farms.

\section{Compatible partners}

A related concern of many considering sharing equipment is how to find compatible partners with whom to share. One grower said that she met potential partners at farming events and continuing education conferences, as well as at the farmers markets where she sells her produce. The aronia group employed an informal "interview" process to screen potential members before inviting them to join. A leader in that group described a suitable partner as someone who "is willing to get their hands dirty." Lack of compatibility in various dimensions can undermine a group's efforts to share equipment. Three fruit and vegetable growers who intended to participate in our project by sharing a plastic mulch remover dropped out because their farm and off-farm job schedules prevented them from adequately communicating with each other. Also, the significant distances between their farms posed difficult and costly transportation logistics. In addition, these growers were at different stages in their lives and differed greatly in their farming experience, which complicated the development of a feasible, mutually agreed upon sharing agreement, given divergence in their willingness to commit to a potential long-term partnership.

In addition to compatible personalities, groups also may need to consider the compatibility of each other's equipment and production systems. Differences are not necessarily insurmountable, but plans must be devised to address potential issues. For 
example, some of the aronia growers are certified organic, while others are not. The group met this challenge by adopting a strict policy of cleaning and washing the machine after each use at the place of harvest before it was moved to the next location. A gas-operated pressure washer travels with the harvester, an organic-approved cleaning solution is used, and the cleaning is recorded on equipment log sheets that travel with the harvester.

For many beginning small-scale fruit and vegetable operators, an additional challenge is finding a skilled equipment operator. There can be a significant learning curve for operating farm machinery safely. For groups sharing more complex machinery, having a member of the group who is an experienced operator is a big advantage. In the aronia berry group, they chose a dedicated operator to run the machine.

Unlike a lawn mower that works the same in most backyard situations, farm equipment may not perform the same from field to field, under a variety of soil types and terrain, and when pulled by different sizes and types of tractors. Even equipment that appears relatively easy to operate, such as the plastic mulch layer and the Eco-Weeder, requires some initial time to learn how to adjust and run in different fields. When a shared machine is complicated to operate, having a lead partner or coordinator experienced with operating and maintaining the machine may be helpful. In such cases, machinery-sharing agreements should identify this individual and specify how and by whom the machine will be maintained or repaired.

\section{Grower Feedback After First Year}

A follow-up, post-project anonymous survey was completed by nine of the 18 participating farmers. Although none of the farmers reporting said they recouped the investment costs in the first year as a result of labor savings, five individuals reported that it has helped improve efficiency on their farms. Four farmers said that although they haven't yet recouped their costs, it was valuable to them to work within a group. Results showed that all of the groups continue to share equipment in the year after the study. All respondents said that the practice of sharing in their group has improved, with eight reporting some improvement and one farmer noting it has improved considerably. However, one farmer added that sharing equipment was often more work that it was worth.

Forming a business group to share machinery also led to some other joint ventures, with six respondents reporting that their group purchased additional equipment to share, while four shared labor, three purchased inputs together, and two jointly marketed produce as a group.

The written machinery-sharing agreement each group developed as part of the project was rated as being of different value and use among the groups during the first year. One farmer said it was very important to their group and they referred to it often; five of those responding felt their agreement was somewhat important to their group and they referred to it occasionally; and two respondents said that members of their group have not referred to their agreement.

\section{Discussion}

This research extends the existing literature on machinery sharing, which has focused primarily on row crop and livestock operations, to sharing among small-scale fruit and vegetable farmers. Many of our findings are consistent with previous research on equipment sharing among row crop and livestock producers. We find that inter-farm cooperation through machinery sharing gives growers access to specialized machinery that improves production efficiency, reduces labor, and facilitates scaling-up production. In some cases, sharing equipment led to cooperation in other areas, such as input purchases and marketing. We found that many of the challenges cited in previous studies, such as scheduling of use and added management costs, were overcome with careful planning and frequent, transparent communication among partners.

One feature that distinguishes the growers in our study from previous research is the very smallscale and local market orientation of their farms. The existing case study and simulation studies have focused on more conventional commodity row crop and livestock operations that have already achieved large-scale production, often sharing machines costing several hundred thousand U.S. dollars or more. Among growers oriented toward 
local foods markets, however, interest in sharing has several strategic motivations. Sharing may reduce variable costs by substituting capital for more expensive labor, but also free up labor for valuable management time of the grower-manager. The potential to increase scale by sharing can lower fixed costs by spreading investment over greater output. Increased scale may also create new marketing opportunities.

This is important as demand for local foods grows, especially among institutional and wholesale buyers, as the ability of producers to meet the demand will depend on their capacity to deliver consistent products in large quantities at lower margins. There are a variety of ways to accomplish this, including aggregating product from many small producers. However, while aggregating output may create marketing opportunities, it does not help lower production costs. Economics suggest that both the explicit and implicit costs will be lower for larger scale operations. Larger farms have lower costs per unit, making them more competitive in wholesale markets, where they can supply large volumes of product at lower prices and still be profitable. Due to transaction costs, procurement managers prefer to deal with fewer suppliers, giving growers with scale an additional edge in the market.

For small-scale growers, the decision to mechanize is not always straightforward. Machinery costs are a large share of total expenditures for the smallest farms. According to the USDA's Farm Production Expenditures 2014 Summary, expenditures for farm machinery average 20 percent of total farm production expenditures for farms reporting US $\$ 10,000$-US $\$ 49,999$ gross sales. The corresponding percentage for farms in the next size category (US $\$ 50,000$ to US $\$ 99,999$ gross sales) is 11 percent, and the proportion continues to fall as size increases. On the smallest farms, machinery ownership can be difficult to justify because without sufficient size, the equipment will be underutilized and the cost per output unit will be very high. Sharing equipment with others is one way to spread the machinery costs over more output, achieving some of the advantages of scale without necessarily expanding. More importantly for smallscale growers in our study, sharing is a path to mechanization. Mechanization, in turn, facilitates expansion. Sharing can be a transitional strategy for some growers, freeing up some cash flow and labor to facilitate expansion by reducing machinery expenses during the growth stage.

These results provide examples of successful cooperative arrangements among very small-scale growers, and contribute to an understanding of "best practices" for machinery sharing among farmers. The cases also help build awareness of machinery sharing as an option for growers and can be part of a "toolkit" for resource providers working with growers in the local foods industry.

While there is no "one-size-fits-all" model, we learned several lessons that are applicable to most machinery-sharing arrangements. First, trust among the partners and clarity in communication are critical factors for making shared equipment arrangements successful. This is especially true during the formation stage of the partnerships. Written operating agreements that both are legally enforceable and detail the rules of the sharing arrangement can help create trust among the partners. Having the terms of dissolution if one or more partners should decide to leave the group described in an operating agreement can make the process much smoother, as occurred in the toolbar case when one partner, and then another, quit farming and no longer had a reason to participate in the sharing arrangement. The third partner, who is still farming, was able to purchase the toolbar from her exiting partner at a price they had agreed to in advance. She noted, "I'm very glad we made that agreement because it made decision making a lot easier. It was really easy to figure out how I was to legally acquire that piece of equipment."

A second lesson is the importance of finding compatible partners. The participating farmers often noted the importance of working with "likeminded" individuals, while at the same time valuing a diverse and complementary set of skills, strengths, and interests among the members that strengthen the overall team. Participants conveyed a sense that "the sum may be greater than the parts." Having farms with similar production methods, such as certified organic, makes the use and maintenance of shared machinery much easier and less complicated. 


\section{Conclusions}

Machinery sharing has the potential to help smallscale fruit and vegetable growers gain access to specialized machinery and improved efficiency in cost-effective ways. For growers considering expanding production, sharing can be a practical option. Furthermore, sharing can provide other benefits, including access to skilled labor, reduced risk, and a peer group of like-minded individuals with whom to share ideas. Commonly cited concerns with machinery sharing, including having access to the equipment when most needed, can be overcome with careful advanced planning and open communication. Cooperative Extension services and farmer organizations can play a supporting role for the formation of machinery-sharing groups by providing educational resources and membership networking opportunities.

It is important to note that equipment sharing is not appropriate in all situations. Depending on the labor a machine would replace, the difficulty of the task to be mechanized, and the costs of mileage and time spent in transport, sharing may not make economic sense. Furthermore, sharing equipment is not for everyone. Group collaboration requires trusting other members and a willingness to be flexible when things do not go as planned. While machinery sharing is not a one-size-fits-all solution for expanding production, our study demonstrates that in some cases it has the potential to help growers reduce labor and increase both efficiency and profitability. In the end, growers must weigh the risks and benefits of collaborating specific to their particular farming operation.

\section{Acknowledgements}

The authors would like to thank the cooperating farmers for their time and feedback on machinery sharing. We gratefully acknowledge the helpful comments of three anonymous reviewers and the editor of this journal, which have greatly improved this manuscript.

\section{References}

Allen, D. W., \& Lueck, D. (1998). The nature of the farm. Journal of Law and Economics, 41(2), 343-386. http://dx.doi.org/10.1086/467393
Andersson, H., Larsén, K., Lagerkvist, C.-J., Andersson, C., Blad, F., Samuelsson, J., \& Skargren, P. (2005). Farm cooperation to improve sustainability. AMBIO, 34(3), 383-387. http://dx.doi.org/10.1579/0044-7447-34.4.383

Artz, G. (2014). Equipment sharing in agriculture. Encyclopedia of Food and Agricultural Ethics, 1-6. Retrieved from http://www.springerreference. com/docs $/ \mathrm{html} / \mathrm{chapterdbid} / 307572 . \mathrm{html}$

Artz, G., Colson, G., \& Ginder, R. (2010). A return of the threshing ring? A case study of machinery and labor-sharing in Midwestern farms. Journal of Agricultural and Applied Economics, 42(4), 805-819.

Artz, G., Edwards, W., \& Jarboe, D. (2014). Machinery management for small- and medium-sized horticultural farms (Competitive Grant Report M2012-11). Retrieved from http://www.leopold.iastate.edu/sites/ default/files/grants/M2012-11.pdf

Artz, G. M., Edwards, W., \& Olson, F. E. (2009). Farm machinery \& labor sharing manual: Tools to help you evaluate sharing machinery and labor as an option in your farming operation. Ames, Iowa: MidWest Plan Service.

Artz, G., Naeve, L., \& Edwards, W. (2014). Machinery sharing manual for fruit and vegetable producers. Available from https://store.extension.iastate.edu/Product/ Machinery-Sharing-Manual-for-Fruit-andVegetable-Producers

Basnet, A., \& Kenkel, P. L. (2012, February). Feasibility assessment of biomass harvesting cooperative. Selected paper presented at the annual meetings of the Southern Agricultural Economics Association, Birmingham, Alabama.

Brown, C., \& Miller, S. (2008). The impacts of local markets: A review of research on farmers markets and community supported agriculture (CSA). American Journal of Agricultural Economics, 90(5), 1298-1302. http://dx.doi.org/10.1111/j.14678276.2008.01220.x

de Toro, A., \& Hansson, P.-A. (2004). Machinery cooperatives-A case study in Sweden. Biosystems Engineering, 87(1), 13-25. http://dx.doi.org/ 10.1016/j.biosystemseng.2003.10.010

Edwards, W. (2013). Machinery management: joint machinery ownership (Pub. No. PM 1373). Ames: Iowa State University Extension. Retrieved from https://www.extension.iastate.edu/agdm/crops/ html/a3-34.html 
Gertler, M. E. (1981). A comparison of agricultural resource management on selected group and individual farms in Saskatchewan (Master's thesis). McGill University, Montreal, Canada.

Gertler, M. E., \& Murphy, T. (1987). The social economy of Canadian agriculture: Family farming and alternative futures. In B. Galeski \& E. Wilkening (Eds.), Family farming in Europe and America (pp. 239-270). Boulder, Colorado: Westview Press.

Groger, B. L. (1981). Of men and machines: Cooperation among French family farmers. Ethnology, 20(3), 163-176. http://dx.doi.org/10.2307/3773224

Hansmann, H. (2000). The ownership of enterprise. Cambridge, Massachusetts: Harvard University Press.

Harper, D. (2001). Changing works: Visions of a lost agriculture. Chicago: University of Chicago Press.

Harris, A., \& Fulton, M. (2000a). The CUMA farm machinery co-operatives. Saskatoon Centre for the Study of Co-operatives, University of Saskatchewan.

Harris, A., \& Fulton, M. (2000b). Farm machinery cooperative: An idea worth sharing. Saskatoon: Centre for the Study of Co-operatives, University of Saskatchewan.

Hendrickson, J. (2005). Grower to grower: Creating a livelihood on a fresh market vegetable farm. Retrieved from http://www.cias.wisc.edu/wp-content/ uploads $/ 2008 / 07 /$ grwr2grwr.pdf

Holderness, C. G. (2003). Joint ownership and alienability. International Review of Law and Economics, 23(1), 75-100. http://dx.doi.org/10.1016/S0144$\underline{\text { 8188(03)00015-2 }}$

Johnson, N. L., \& Ruttan, V. W. (1994). Why are farms so small? World Development, 22(5), 691-706. http://dx.doi.org/10.1016/0305-750X(94)90044-2

Kenkel, P., \& Long, G. (2007a, February). Feasibility of machinery cooperatives in the Southern Plains region. Selected paper presented at the meeting of the Southern Agricultural Economics Association, Mobile, Alabama.

Kenkel, P., \& Long, G. (2007b, November). Structural considerations for machinery cooperatives. Selected paper presented at the NCERA-194 annual meeting, Minneapolis, Minnesota.

Kennedy, P. L., \& Luzar, E. J. (1999). Toward methodological inclusivism: The case for case studies. Review of Agricultural Economics, 21, 579-591.
Larsén, K. (2007, July). Participation, incentives and social norms in partnership arrangements among farms in Sweden. Paper presented at the annual meetings of the American Agricultural Economics Association, Portland, Oregon.

Low, S. A., \& Vogel, S. (2011). Direct and intermediated marketing of local foods in the United States (Economic Research Report No. 128). Retrieved from http://www.ers.usda.gov/publications/erreconomic-research-report/err128.aspx

Low, S. A., Adalja, A., Beaulieu, E., Key, N., Martinez, S., Melton., A.,...Jablonski, B. B. R. (2015). Trends in U.S. local and regional food systems (Administrative Publication No. 068). Retrieved from http://www.ers.usda.gov/publications/apadministrative-publication/ap-068.aspx

Mount, P. (2012). Growing local food: Scale and local food systems governance. Agriculture and Human Values, 29(1), 107-121. http://dx.doi.org/10.1007/s10460-011-9331-0

Nielsen, V. (1999). The effect of collaboration between cattle farms on the labour requirement and machinery costs. Journal of Agricultural Engineering Research, 72(2), 197-203. http://dx.doi.org/10.1006/jaer.1998.0363

Olmstead, A. L., \& Rhode, P. W. (1995). Beyond the threshold: An analysis of the characteristics and behavior of early reaper adopters. Journal of Economic History, 55(1), 27-57. http://dx.doi.org/10.1017/S0022050700040560

Ostrom, E. (1990). Governing the commons: The evolution of institutions for collective action. New York: Cambridge University Press.

Samuelsson, J., Larsén, K., Lagerkvist, C. J., \& Andersson, H. (2008). Risk, return and incentive aspects on partnerships in agriculture. Food Economics, 5(1), 14-23. http://dx.doi.org/10.1080/16507540802172782

Scottish Agricultural Organisation Society. (2008). Cooperative rural business rings socio economic impact study. Ingliston: Scottish Agricultural Organisation Society.

Sexton, R. J., \& Iskow, J. (1988). Factors critical to the success or failure of emerging agricultural cooperatives (Gianini Foundation Information Series No. 88-3). Davis: University of California, Davis.

Sterns, J. A., Schweikhardt, D. B., \& Peterson, H. C. (1998). Using case studies as an approach for conducting agribusiness research. International Food and Agribusiness Management Review, 1, 311-327. 
Valentinov, V. (2007). Why are cooperatives important in agriculture? An organizational economics perspective. Journal of Institutional Economics, 3(1), 55-69. http://dx.doi.org/10.1017/S1744137406000555

Weness, E. (2001, August). Sharing farm machinery. St. Paul: University of Minnesota Extension.

Westgren, R. and K. Zering. (1998, September/October). Case study research methods for firm and market research. Agribusiness, 14, 415-424.

Wolfley, J. L., Mjelde, J. W., Klinefelter, D. A., \& Salin, V. (2011). Machinery-sharing contractual issues and impacts on cash flows of agribusinesses. Journal of
Agricultural and Resource Economics, 36(1), 139-159. Retrieved from http://www.jstor.org/stable/ 23243138

U.S. Department of Agriculture. (2014). Obama Administration announces additional support to belp communities boost local food economies [News release]. Retrieved from http://www.usda.gov/wps/portal/ usda/usdamediafb? contentid $=2014 / 06 / 0114 . x m l \&$ printable $=$ true $\&$ contentidonly $=$ true

Yin, R. K. (2003). Case study research: Design and methods (3rd ed.). Thousand Oaks, California: Sage Publications. 


\section{Appendix. Preliminary Questionnaire}

\section{ABOUT YOUR GROWERS' GROUP}

Is this the first effort you have made to share equipment as a group? Yes No

What is the approximate distance (road miles) between farms in your group?

What factors played a role in determining what piece of equipment you intend to purchase and share? (check all that apply)

\section{Cost}

Portability

Priority need by all in the group

Easily adjusted to fit different tractors

Timing of use isn't as critical

Easy to store

Seasonal equipment

Opportunity to save labor

Other: 


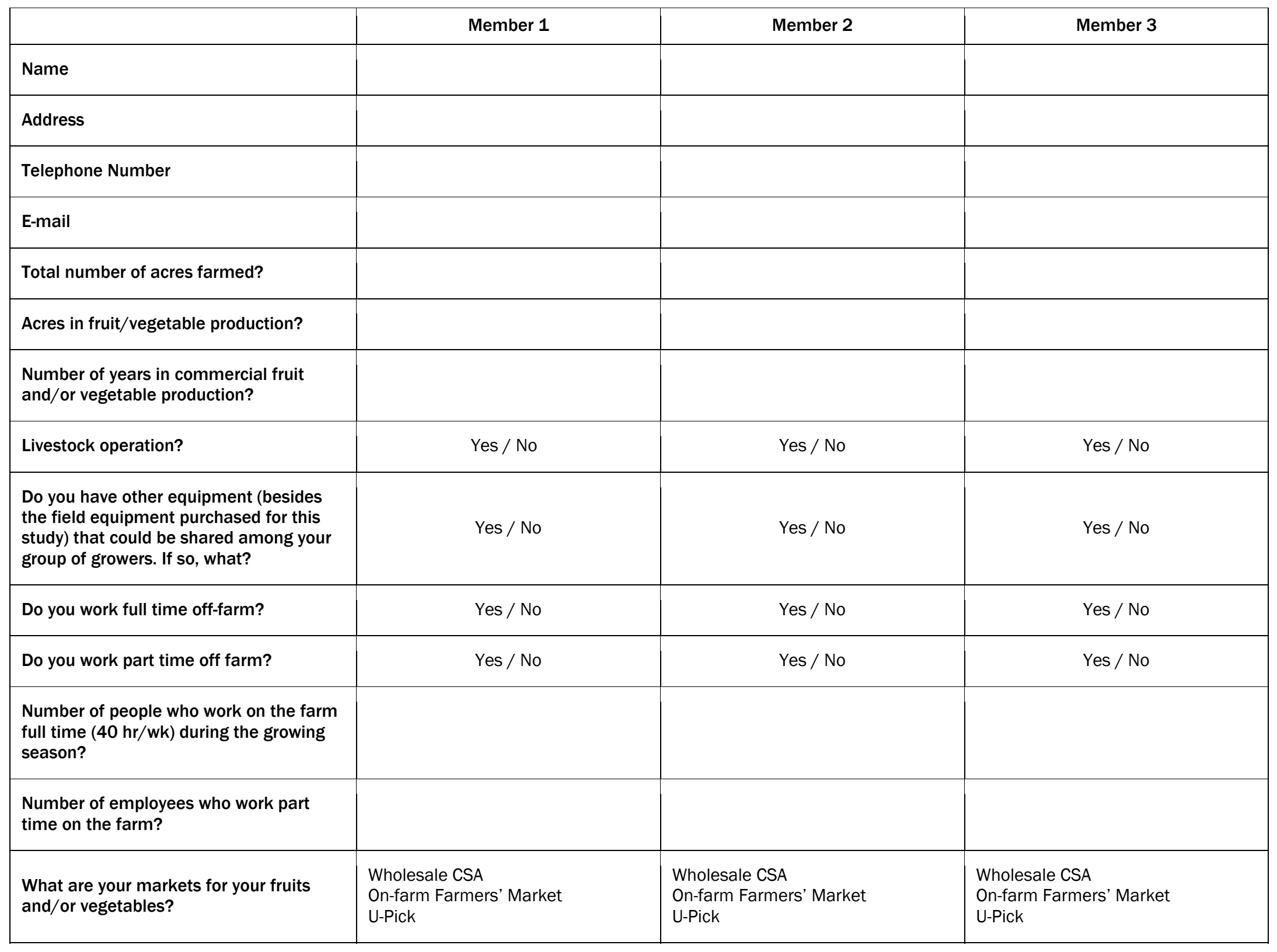

